\title{
Usefulness of combining electrocardiogram and echocardiography findings and brain natriuretic peptide in early detection of cardiac amyloidosis in subjects with transthyretin gene mutation
}

\author{
Gianluca Di Bella ${ }^{1 *}$, Fabio Minutoli ${ }^{2}$, Anna Mazzeo ${ }^{3}$, Matteo Cssale$^{1}$, Claudia Stancanelli ${ }^{3}$, Scipione Carerj ${ }^{1}$, \\ Sergio Baldari ${ }^{2}$, Giuseppe Vita ${ }^{3}$
}

From First European Congress on Hereditary ATTR amyloidosis

Paris, France. 2-3 November 2015

Early non-invasive identification of cardiac amyloidosis (CA) is of growing clinical importance. Low voltage on electrocardiogram (ECG), increased left ventricular (LV) septal thickness (ST) and global longitudinal strain (GLS) on echocardiography, and elevated brain natriuretic peptides (BNP) are used as surrogates of CA. Thirtyfive patients (50 \pm 14 years, 22 females) underwent an ECG to analyze low-voltage QRS $(<15 \mathrm{mV})$ pathological Q-waves, poor R-wave progression, ST-T abnormalities - and left bundle branch block. An ECG was considered abnormal if at least one ECG alteration was present. Echocardiography was used to analyze LVST, E/E' and GLS. All participants also had BNP blood testing. $99 \mathrm{mTc}-\mathrm{DPD}$ scintigraphy assumed as a reference method showed CA in 18 patients (51\%, CA group) and no accumulation in 17 patients (no CA group). In descending order of accuracy, LVST $>14 \mathrm{~mm}, \mathrm{E} / \mathrm{E}^{\prime}>6.6$, GLS $<14.1$, BNP $>129 \mathrm{pg} / \mathrm{ml}$, and an overall abnormal ECG showed good capability to distinguish patients with and without $C A$. All these parameters were predictors of CA in univariate analysis while low-voltage QRS showed the worst performance. LVST $>14 \mathrm{~mm}(\mathrm{p}=$ 0.002 ) was the best independent predictor of CA, achieving sensitivity of $78 \%$ and accuracy of $89 \%$. However, a LVST $>14 \mathrm{~mm}(\mathrm{p}=0.005)$ plus an abnormal ECG $(p=0.03)$ show together a higher sensitivity, equal to $89 \%$, in identifying CA. An integrated evaluation of ECG and echocardiography is a sensitive and low-cost

${ }^{1}$ University of Messina, Clinical and experimental medicine department, 98100, Messina, Italy

Full list of author information is available at the end of the article technical approach to identify CA in patients with transthyretin gene mutation.

\section{Authors' details}

University of Messina, Clinical and experimental medicine department, 98100, Messina, Italy. ${ }^{2}$ University of Messina, Department of Biomedical Sciences and of Morphologic and Functional Images, 98100, Messina, Italy. ${ }^{3}$ University of Messina, Department of Neurosciences, 98100, Messina, Italy.

\section{Published: 2 November 2015}

\section{doi:10.1186/1750-1172-10-S1-P34}

Cite this article as: Di Bella et al:: Usefulness of combining

electrocardiogram and echocardiography findings and brain natriuretic peptide in early detection of cardiac amyloidosis in subjects with transthyretin gene mutation. Orphanet Journal of Rare Diseases 2015 10(Suppl 1):P34.

Submit your next manuscript to BioMed Central and take full advantage of:

- Convenient online submission

- Thorough peer review

- No space constraints or color figure charges

- Immediate publication on acceptance

- Inclusion in PubMed, CAS, Scopus and Google Scholar

- Research which is freely available for redistribution 